Sains Malaysiana 50(2)(2021): 373-381

http://dx.doi.org/10.17576/jsm-2021-5002-09

\title{
Degradation of Nonylphenol Ethoxylate-10 (NPE-10) by Mediated Electrochemical Oxidation (MEO) Technology
}

(Degradasi Nonilfenol Etoksilat-10 (NPE-10) oleh Teknologi Gerak Balas Pengoksidaan Elektrokimia (MEO))

\author{
Henry Setiyanto*, Muhammad. Muslim Syaifullah, I Made Adyatmika, Dian Ayu Setyorini, \\ Muhammad Yudhistira Azis, Vienna Saraswaty \& Muhammad Ali Zulfikar
}

\begin{abstract}
Nonylphenol ethoxylate (NPE-10) is a non-ionic surfactant that is synthesized from alkylphenol ethoxylate. The accumulation of NPE-10 in wastewater will endanger the ecosystem as well as the human being. Nowadays, NPE-10 can be degraded indirectly by using an electrochemical treatment by the advancement of technology. Thus, this study is aimed to evaluate the electro-degradation potential of NPE-10 by MEO using Ce(IV) ionic mediator. In addition, the influence of $\mathrm{Ag}(\mathrm{I})$ ionic catalyst in the performance of MEO for the degradation of NPE-10 was also observed. The potency of MEO technology in the NPE-10 degradation was evaluated by voltammetry technique and confirmed by titrimetry and LC-MS analysis. The results showed that in the absence of $\mathrm{Ag}(\mathrm{I})$ ionic catalyst, the degradation of NPE-10 by MEO was $85.93 \%$. Furthermore, when the Ag(I) ionic catalyst was applied, the performance of MEO in degradation of $\mathrm{NPE}-10$ was improved to $95.12 \%$. The back titration using $\mathrm{Ba}(\mathrm{OH})_{2}$ confirmed the formation of $\mathrm{CO}_{2}$ by $46.79 \%$, whereas the redox titration shows the total of degradation organic compounds by $42.50 \%$. It was emphasized by the formation of two new peaks in the LC-MS chromatogram. In summary, our results confirmed the potential of MEO technology for the NPE-10 degradation.
\end{abstract}

Keywords: Ag(I) catalyst ion; Ce(IV) mediator ion; degradation; mediated electrochemical oxidation; NPE-10

ABSTRAK

Nonilfenol etoksilat (NPE-10) merupakan bahan surfaktan tidak berion yang disintesiskan daripada alkil fenol etoksilat. Pengumpulan NPE-10 dalam air buangan akan membahayakan ekosistem dan juga manusia. Hari ini, NPE10 dapat digradasikan secara tidak langsung dengan penggunaan rawatan elektrokimia oleh teknologi yang maju. Oleh itu, kajian ini adalah untuk mengkaji potensi degradasi elektro terhadap bahan NPE-10 oleh teknologi MEO dan menggunakan ion Ce(IV) sebagai bahan perantara. Selain itu, pengaruh pemangkin ion Ag(I) dalam prestasinya kepada teknologi MEO untuk degradasi NPE-10 diperhati. Potensi teknologi MEO dalam degradasi NPE-10 telah dinilai daripada teknik voltametri dan disahkan dengan kaedah titrimetri dan analisis LC-MS. Keputusan kajian menunjukkan bahawa dengan ketiadaan pemangkin ion Ag(I), prestasi degradasi NPE-10 melalui teknologi MEO adalah 85.93\%. Selain itu, apabila pemangkin ion Ag (I) digunakan, potensi MEO untuk degradasi NPE-10 ditingkatkan kepada 95.12\%. Pentitratan balik menggunakan $\mathrm{Ba}(\mathrm{OH})_{2}$ mengesahkan bahawa terdapat penghasilan $\mathrm{CO}_{2}$ sebanyak 46.79\%, sedangkan titrasi redoks menunjukkan jumlah sebatian organik yang digradasi sebanyak 42.50\%. Jumlah degradasi ini ditekankan dengan penghasilan dua puncak daripada analisis kromatogram LC-MS. Secara kesimpulannya, keputusan kajian kami sah bahawa potensi teknologi MEO dalam degradasi NPE-10.

Kata kunci: Degradasi; ion perantara Ce(IV); gerak balas pengoksidaan elektrokimia; NPE-10; pemangkin ion Ag(I)

\section{INTRODUCTION}

NPE is one of a non-ionic surfactant in the class of alkylphenol ethoxylates. NPE is widely used as dispersing agent in household, industrial applications, detergent, as well as emulsifier (Brigden et al. 2012; Fuente et al. 2010; Martins et al. 2006). The toxicity of NPE is relatively low. However, due to the significant increase of usage of this organic pollutant and its potential to produce highly toxic and stable metabolites such as ethylene oxide, as well as its slow biodegradation, NPE can cause serious environmental problems. More importantly, according to a toxicity evaluation, this compound also considered 
as an endocrine disrupting compound which may result in functional abnormalities as well as cancer (Forte et al. 2016; Liu et al. 2017; Shufaro et al. 2018). Several approaches have been developed for NPE degradation including biological treatment, as shown by studies of Hernandez-Raquet et al. (2007), Lu et al. (2007), Maki et al. (1994), and Mao et al. (2012) whose results successfully degraded NPE in ranging of $60-100 \%$. However, those biological treatments of NPE may cause other problems as they have the following characteristics: Potential in reducing oxygen transfer, producing foams, disturbing the sedimentation process and disturbing the ecosystem. For the aforementioned reasons, the procedure in the degradation of NPE needs to be established.

Electrochemical based technology offers multiple advantages such as environmental compatibility, versatility, and cost effective. MEO is one of the electrochemical treatments which is commonly used for the degradation of organic pollutants based on the activity of oxidant species (ionic mediators), including $\mathrm{Ce}(\mathrm{IV}), \mathrm{Cl}$ and $\mathrm{S}_{2} \mathrm{O}_{8}{ }^{2-}$ (Juttner et al. 2000). Due to the nature of NPE as an electro-active organic compound, MEO is possible to be applied for the degradation of NPE. The principle of redox reaction is by electron transfer mechanism (Setiyanto et al. 2015, 2011a, 2011b) was used in this study.

NPE-10 (Figure 1) is one of the most common nonionic surfactant (Cox et al. 1984; Olkowska et al. 2014). The maximum concentration of NPE-10 allowed in the freshwater and saltwater should not exceed 6.6 and 1.7 $\mu \mathrm{g} / \mathrm{L}$ (Brooke \& Thursby 2005; David et al. 2009). Since no study has been reported about the degradation of NPE10 by MEO technology, we are interested to evaluate the potential of MEO in the degradation of NPE- 10.

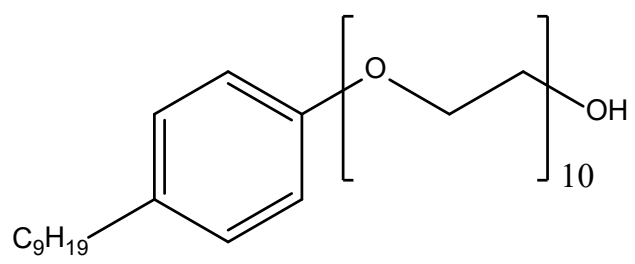

FIGURE 1. Structure of NPE-10

In this paper, the potential of MEO in NPE-10 degradation was evaluated by voltammetry techniques and confirmed by back titration, redox titration, and LC-MS analyses. In addition, we also evaluated the influence of the addition of $\mathrm{Ag}(\mathrm{I})$ ionic catalyst in the MEO performance for NPE-10 degradation.

\section{MATERIALS AND METHODS}

\section{APPARATUS}

The degradation process was carried out by using Potensiostat/Galvanostat eDAQ 410 with Pt wire as the cathode and anode. The degradation product was evaluated by voltammetric techniques using BASi Epsilon Electrochemical Analyzer. The voltammetric detection used three electrodes: Carbon paste electrode (CPE) as the working electrode, $\mathrm{Ag} / \mathrm{AgCl}$ as the reference electrode, and $\mathrm{Pt}$ wire as the auxiliary electrode. The product of the degradation was further analyzed using LC-MS XEVO Qtof - MS instrument.

\section{CHEMICALS}

The cerium sulfate octahydrate ( $>99.0 \%$ ) was purchased from (Sigma Aldrich). Sodium chloride, barium dioxide, potassium permanganate, oxalate acid, hydrochloric acid, $\mathrm{Al}_{2} \mathrm{O}_{3}$, sulphuric acid, and graphite were from Merck with pro analytical grade. NPE-10 was purchased from a local textile shop with technical grade.

PREPARATION OF THE WORKING ELECTRODE

The working electrode (CPE) was prepared by several steps. First, the mixture of carbon and liquid paraffin (in the ratio of $7: 3$ ) was heated at $80{ }^{\circ} \mathrm{C}$ in a beaker glass. Then, the mixtures were inserted to a cylindrical electrode holder and cooled in room temperature. For the electrical contact, the carbon paste was connected with a copper wire. The surface of the prepared working electrode was then polished by alumina $\left(\mathrm{Al}_{2} \mathrm{O}_{3}\right)$ slurry onto a polishing pad.

\section{SAMPLE PREPARATIONS AND VOLTAMMETRIC MEASUREMENT}

The oxidation potential of Ce(III) and NPE-10 were investigated by using voltammetric method. Four solutions were prepared in $0.2 \mathrm{M} \mathrm{H}_{2} \mathrm{SO}_{4}$ : (1) background solution (0.4 $\mathrm{M} \mathrm{H}_{2} \mathrm{SO}_{4}$ ); (2) $0.04 \mathrm{M} \mathrm{Ce}$ (III); (3) $1000 \mathrm{ppm}$ NPE-10; (4) the mixture of $0.04 \mathrm{M} \mathrm{Ce}(\mathrm{III})$ and $1000 \mathrm{ppm}$ NPE-10. The measurement was recorded in the scan range of $-200-2000 \mathrm{mV}$ with the scan rate of $100 \mathrm{mV} / \mathrm{s}$ using cyclic voltammetry.

For measurement optimization, four solutions were prepared in a $0.4 \mathrm{M} \mathrm{H}_{2} \mathrm{SO}_{4}$ containing: (a) $1500 \mathrm{ppm}$ NPE-10; (b) $0.04 \mathrm{M} \mathrm{Ce(III)} \mathrm{and} 1500$ ppm NPE-10; (c) $0.04 \mathrm{M} \mathrm{Ce}(\mathrm{III}), 0.009 \mathrm{M} \mathrm{Ag}(\mathrm{I})$, and 1500 ppm NPE-10. The duration of degradation was varied from 5 to $55 \mathrm{~min}$. The solution after degradation was further evaluated by voltammetric techniques. 


\section{LC-MS ANALYSIS}

LC-MS analysis was performed by the LC-MS XEVO Qtof - MS instrument. The column used was ACQUITY UPLC BEH C18 $(1,7 \mu \mathrm{m} \times 2,1 \mathrm{~mm} \times 100 \mathrm{~mm})$. The flow rate was $0.3 \mathrm{~mL} / \mathrm{min}$ with the injection volume of $5 \mu \mathrm{L}$. For the separation of degradation products, the following solvents were used: $2 \mathrm{mM}$ ammonium acetate in water (A) and $2 \mathrm{mM}$ ammonium acetate in acetonitrile (B).

\section{INDIRECT DETERMINATION OF CARBON DIOXIDE BY BACK TITRATION}

The content of $\mathrm{CO}_{2}$ gas formed during degradation of NPE-10 by MEO was evaluated by back titration using $\mathrm{Ba}(\mathrm{OH})_{2}$ solution. The amount of $\mathrm{Ba}(\mathrm{OH})_{2}$ is equivalent with $\mathrm{CO}_{2}$ according to (1):

$$
\mathrm{Ba}(\mathrm{OH})_{2}(a q)+\mathrm{CO}_{2}(g) \rightarrow \mathrm{BaCO}_{3}(s)+\mathrm{H}_{2} \mathrm{O}(l)
$$

The protocol for indirect determination of $\mathrm{CO}_{2}$ is as follows: The $\mathrm{CO}_{2}$ gas formed during degradation of NPE10 by MEO was fed into an Erlenmeyer flask containing $\mathrm{Ba}(\mathrm{OH})$, solution $(\mathrm{Ba}(\mathrm{OH})$, total at $0.9588 \mathrm{mmol})$. After the degradation process finished, the $\mathrm{Ba}(\mathrm{OH})_{2}$, solution containing $\mathrm{CO}_{2}$ was then titrated with a $0.0282 \mathrm{mmol}$ $\mathrm{HCl}$. The mmol of $\mathrm{Ba}(\mathrm{OH})_{2}$ remained was assumed as the amount of $\mathrm{Ba}(\mathrm{OH})_{2}$ that did not react with the $\mathrm{CO}_{2}$ formed from the NPE-10 degradation and can be shown from (2):

$\left.\mathrm{Ba}(\mathrm{OH})_{2}\right](\mathrm{mmol})=\left[\mathrm{Ba}(\mathrm{OH})_{2}\right]$ total $(\mathrm{mmol})-\left[\mathrm{Ba}(\mathrm{OH})_{2}\right]$ titration $(\mathrm{mmol})$

The percentage of $\mathrm{CO}_{2}$ formed can be calculated by the following formula in (3):

$$
\% \mathrm{CO}_{2}=\frac{\text { mmol of } \mathrm{Ba}(\mathrm{OH}) 2}{\text { mmol CO2 theoretical }} \times 100 \%
$$

where the amount of mmol $\mathrm{CO}_{2}$ theoretical is according to the prediction of $\mathrm{mmol} \mathrm{CO}_{2}$ from the propose NPE- 10 complete degradation reaction on anode and can be shown from equation (4) (Balaji et al. 2007; Chung \& Park 2000):

$$
\begin{aligned}
& \mathrm{C}_{35} \mathrm{H}_{64} \mathrm{O}_{11} /(\mathrm{NPE}-10)+182 \mathrm{Ce}(\mathrm{IV})+59 \mathrm{H}_{2} \mathrm{O} \rightarrow \\
& 35 \mathrm{CO}_{2}+182 \mathrm{Ce}(\mathrm{III})+182 \mathrm{H}^{+}+182 \mathrm{e}^{-}
\end{aligned}
$$

\section{DETERMINATION OF PERMANGANATE VALUE BY REDOX TITRATION}

The percentage of degraded organic compound from NPE10 degradation by MEO was confirmed by redox titration. Prior to the redox titration, the samples were prepared by these following steps: The solution of NPE-10 before and after degradation were diluted for 25 times. About 100 $\mathrm{mL}$ of NPE-10 solution was put into a $300 \mathrm{~mL}$ Erlenmeyer flask and added with a few drops of $0.01 \mathrm{~N} \mathrm{KMnO}_{4}$ until the color of the solution becomes pink. The solution was further added with $5 \mathrm{~mL}$ of an $8 \mathrm{~N}$ sulfuric acid and heated to $105{ }^{\circ} \mathrm{C}$, then cooled in room temperature. About 10 $\mathrm{mL}$ of prepared sample was then pipetted and transferred into an Erlenmeyer flask. Subsequently, the sample was re-heated for $10 \mathrm{~min}$. After $10 \mathrm{~min}$, the solution was added with $10 \mathrm{~mL}$ of a $0.01 \mathrm{~N}$ oxalic acid. The excess oxalic acid was titrated with $0.01 \mathrm{~N} \mathrm{KMnO}_{4}$. The permanganate value was calculated using (5):

$$
\mathrm{KMnO}_{4}(\mathrm{mg} / L)=\frac{[(10-a) \times \mathrm{b}-(10 \times \mathrm{c})] \times 1 \times 31.6 \times 1000}{d} \times
$$

where, ' $a$ ' is the required volume of $\mathrm{KMnO}_{4}$ in the titration, ' $b$ ' is the actual $\mathrm{KMnO}_{4}$ normality, 'c' is the normality of oxalic acid, ' $d$ ' is the volume of the sample, and ' $\mathrm{f}$ ' is the dilution factor (Suslova et al. 2014).

The percentage degraded organic compound can be referred to (6):

KMn04 value $]$ before degradation - [KMn04 value]after degradation $[\mathrm{KMnO} 4$ value $]$ before degradation $100 \%(6)$

\section{RESULTS AND DISCUSSION}

\section{VOLTAMMETRIC STUDY OF CE(III)/CE(IV) AND NPE-10}

The voltammetric behavior of Ce(III) and NPE-10 were observed by using cyclic voltammetry (CV) in $\mathrm{H}_{2} \mathrm{SO}_{4}$ as the supporting electrolyte (Paulenova et al. 2002; Ren \& Wei 2011). The measurement of CV was aimed to determine whether the reaction is reversible or irreversible. As shown in Figure 2, two reduction peaks were observed at the potential value of 0.786 and $0.444 \mathrm{~V}$, respectively. Those peaks were assumed as the reduction peaks of $\mathrm{H}_{2} \mathrm{SO}_{4}$, as suggested by the following prediction reduction reaction in (7) and (8):

$$
\begin{aligned}
& \mathrm{SO}_{4^{2-}}+4 \mathrm{H}^{+}+2 e^{-} \rightleftharpoons \mathrm{SO}_{2}(a q)+2 \mathrm{H}_{2} \mathrm{O} \\
& \mathrm{SO}_{2}(a q)+4 \mathrm{H}^{+}+4 e^{-} \rightleftharpoons \mathrm{S}(s)+2 \mathrm{H}_{2} \mathrm{O}
\end{aligned}
$$

As can also be seen in Figure 2, the voltammogram of $\mathrm{Ce}(\mathrm{III}) / \mathrm{Ce}(\mathrm{IV})$ (black line) showed oxidation and reduction peak current (Ipa and Ipc) at 1.322 and $1.148 \mathrm{~V}$, respectively, indicating reversible reaction. Meanwhile, the voltammogram of NPE-10 (red line) only showed oxidation peak current at $1.400 \mathrm{~V}$, indicating irreversible reaction of NPE-10. As also depicted in Figure 2 (blue line), in the mixture of Ce(III) and NPE-10 solution, the nett of NPE-10 peak oxidation current $(\Delta \mathrm{Ip})$ decreased, indicating the oxidation of NPE-10 due to the reduction reaction of $\mathrm{Ce}(\mathrm{IV})$ into $\mathrm{Ce}(\mathrm{III})$. 


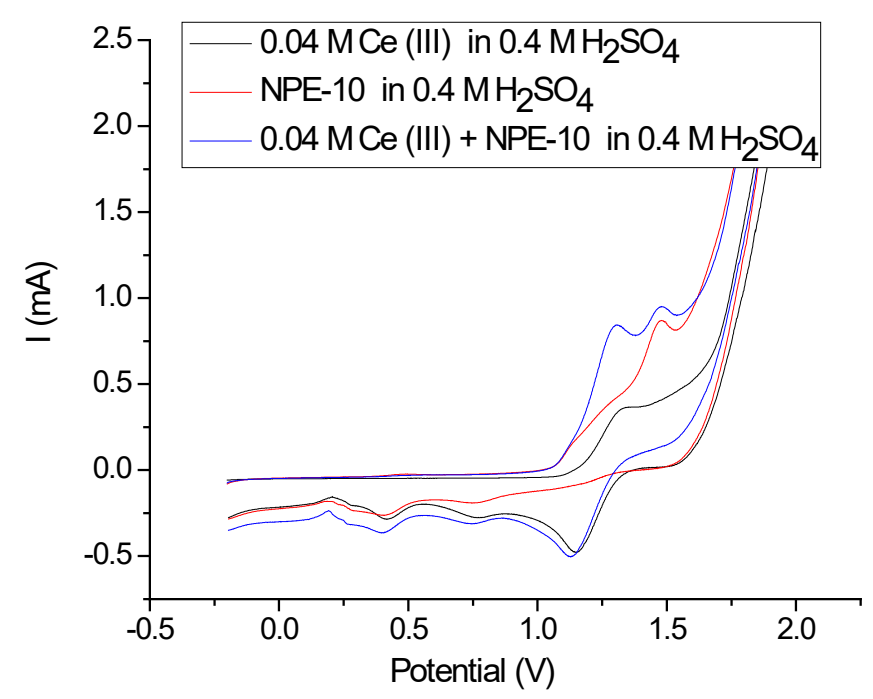

FIGURE 2. The cyclic voltammogram of (a) $0.04 \mathrm{M} \mathrm{Ce(III),} \mathrm{(b)} \mathrm{NPE-}$ 10 , and (c) $0.04 \mathrm{M} \mathrm{Ce}(\mathrm{III})$ and NPE-10 in $0.4 \mathrm{M} \mathrm{H}_{2} \mathrm{SO}_{4}$ by CPE as the working electrode, $\mathrm{Ag} / \mathrm{AgCl}$ as the reference electrode and Pt wire as the auxiliary electrode

SELECTION OF VOLTAMMETRY TECHNIQUE FOR EVALUATION OF NPE-10 DEGRADATION

Prior to the evaluation of NPE-10 degradation, we selected the most suitable voltammetry techniques as suggested by the highest nett current. In this study, four voltammetry techniques were evaluated for NPE-10 degradation: Linear sweep voltammetry (LSV), cyclic voltammetry (CV), differential pulse voltammetry (DPV), and square wave voltammetry (SWV). The NPE-10 solution used in this study was prepared at $5000 \mathrm{ppm}$ in $0.4 \mathrm{M} \mathrm{H}_{2} \mathrm{SO}_{4}$. The value of nett current was presented in Figure 3.

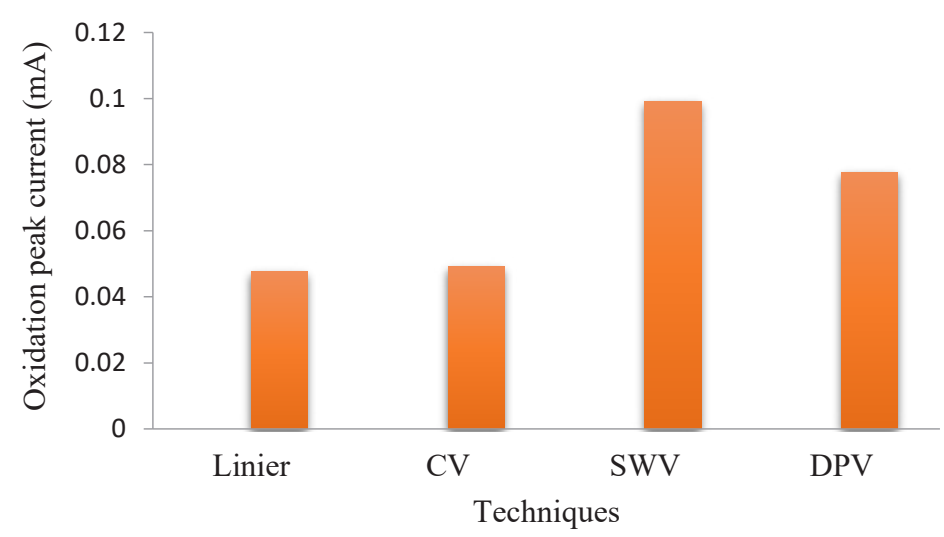

FIGURE 3. The nett current of NPE-10 using various voltammetry technique

As depicted in Figure 3, the nett current values of NPE-10 were $0.0477,0.0491,0.0777$, and $0.0990 \mathrm{~mA}$ for LSV, CV, DPV, and SWV, respectively. Comparison between nett current value of NPE-10 using SWV and other techniques showed that SWV is the most sensitive technique. It has been reported that the limit detection of DPV and SWV were in nanomolar range which are superior than LSV and CV (Hussain \& Silvester 2018). In DPV 
technique, only forward current was measured. Whereas in SWV technique, both the forward and reverse current are measured, hence the higher nett current value was observed by SWV. Our results were in agreement Wang (2000), which reported that SWV was 3.3 times more sensitive than DPV for detection of irreversible compounds.

\section{THE OPTIMIZATION OF NPE-10 DEGRADATION TIME}

In waste treatment, degradation time plays an important role particularly in cost effectiveness. In general, the longer degradation time, the more compound or organic pollutants are degraded and the higher cost is required. However, when the steady state condition is reached, no more compounds will be degraded. Thus, it is very important to optimize the degradation time of NPE-10. In our previous report, we have successfully electro-degraded NPE-10 by MEO at potential value of $5.5 \mathrm{~V}$ (Muslim et al. 2018). The percentage degradation value of NPE-10 was $\sim 80 \%$. In this study, the percentage degradation of NPE-10 as function of time was presented in Figure 4. As shown, the percent degradation of NPE-10 tends to increase at min of 5 to 35 . Whereas at min of 35 to 55 , the percent degradation of NPE-10 is relatively constant. The percent degradation value of NPE-10 at min of 35 was $85.51 \%$. Accordingly, we suggest applying 35 min of degradation time for degradation of 1500 ppm NPE-10 by MEO.

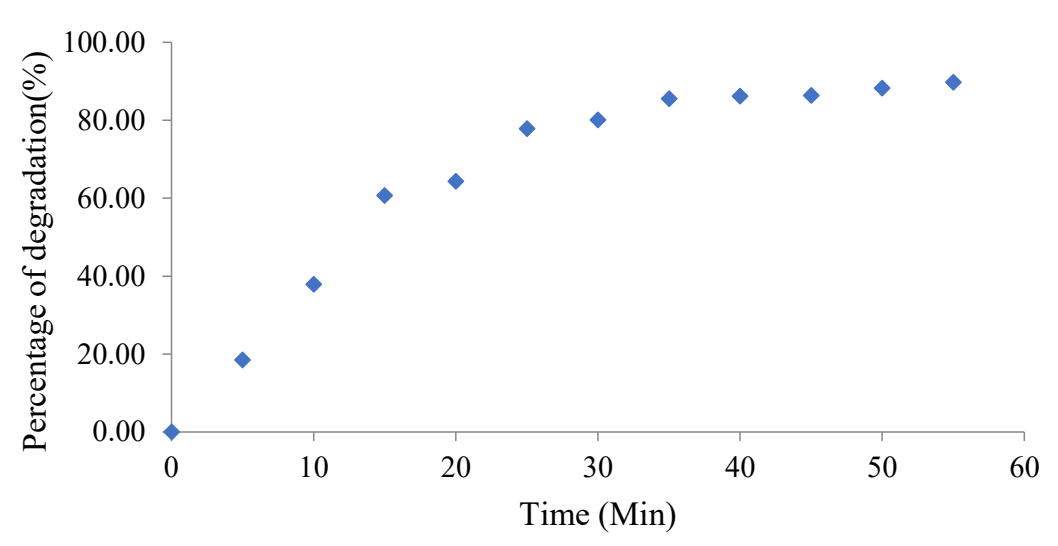

FIGURE 4. Percent degradation of NPE-10 by MEO as function of time

\section{THE EFFECT OF AG(I) CATALYST ION FOR NPE-10 DEGRADATION BY MEO USING CE(IV) IONIC MEDIATOR}

The influence of $\operatorname{Ag}(\mathrm{I})$ ionic catalyst addition in the NPE-10 degradation by MEO was presented in Table 1. As presented, the degradation of NPE-10 by MEO in acidic solution of without $\mathrm{Ce}(\mathrm{III})$, with $\mathrm{Ce}(\mathrm{III})$ and combination of $\mathrm{Ce}(\mathrm{III}) \mathrm{Ag}(\mathrm{I})$ were $61.44,85.93$ and $95.12 \%$, respectively. From Table 1, it is obvious that, the presence of $\mathrm{Ce}(\mathrm{III})$ and $\mathrm{Ag}(\mathrm{I})$ increased the NPE-10 degradation by MEO. It should be noted that in an acidic solution containing $\mathrm{Ce}(\mathrm{III})$, the $\mathrm{Ce}(\mathrm{IV})$ can be produced as the result of redox reaction. The produced Ce(IV) will continuously oxidize NPE-10 (Figure 5) hence resulting degradation products including $\mathrm{CO}_{2}$ (Martinez-Huitle \& Ferro 2006; Raju \& Basha 2005)

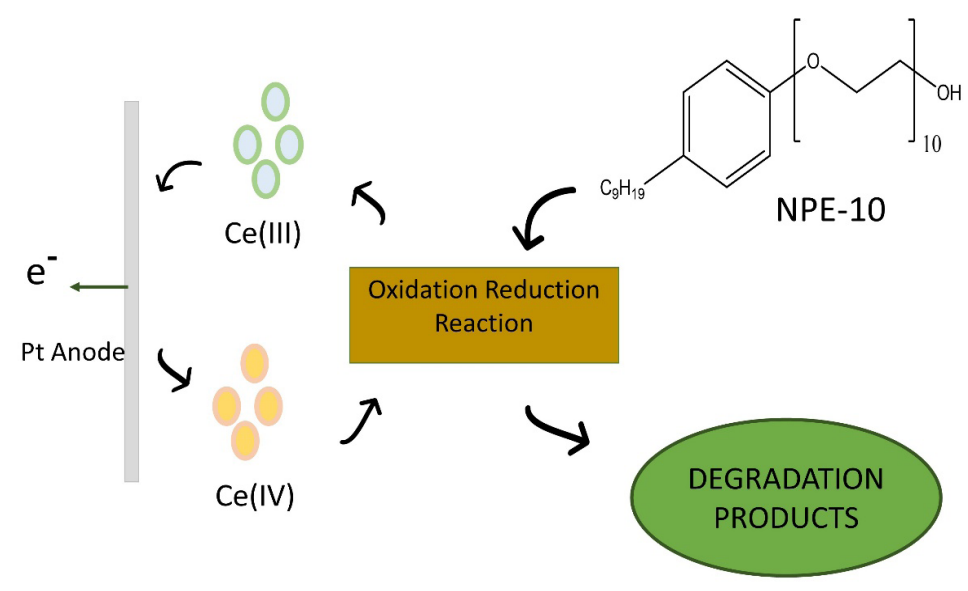

FIGURE 5. The mechanism process of NPE-10 degradation by using $\mathrm{Ce}(\mathrm{IV})$ as mediator ion 
In an acidic solution, $\operatorname{Ag}(\mathrm{I})$ will be oxidized as $\mathrm{Ag}(\mathrm{II}) . \mathrm{Ag}(\mathrm{II})$ is an unstable ion and can act as an oxidator. Therefore, the presence of $\mathrm{Ag}$ (II) in a solution containing $\mathrm{Ce}$ (III) supports the oxidation of $\mathrm{Ce}$ (III) to $\mathrm{Ce}(\mathrm{IV})$. According to the results of NPE-10 degradation in the presence of $\operatorname{Ag}(\mathrm{I})$, we showed that the performance of NPE-10 by MEO was improved. Furthermore, our data were in the line with previous studies which have reported that the presence of $\mathrm{Ag}(\mathrm{I})$ in a solution containing $\mathrm{Ce}(\mathrm{III})$ will increase the oxidation peak current of Ce(III) (Fawzy \& Al-Jahdali 2016; Matheswaran et al. 2007; Sumathi et al. 2010). Based on these explanation, $\operatorname{Ag}(\mathrm{I})$ has the potential as an ionic catalyst in the redox reaction of $\mathrm{Ce}(\mathrm{III}) / \mathrm{Ce}(\mathrm{IV})$. Therefore, we suggest to add $\mathrm{Ag}(\mathrm{I})$ in acidic solution of Ce(III) for the electro-degradation of NPE-10 by MEO to achieve a better result.

TABLE 1. The percent degradation of NPE-10 in acidic solution

\begin{tabular}{lc}
\hline \multicolumn{1}{c}{ Condition of NPE-10 degradation } & Percentage of degradation (\%) \\
\hline Without 0.04 M Ce(III) & 61.44 \\
Containing 0.04 M Ce(III) & 85.93 \\
With 0.04 M Ce(III) and 0.009 M Ag(I) & 95.12 \\
\hline
\end{tabular}

\section{DEGRADATION OF NPE-10 BY MEO RESULTING $\mathrm{CO}_{2}$}

In anode, the degradation of NPE-10 was predicted to form $\mathrm{CO}_{2}$ (see the propose reaction 2). We confirmed that the formation of $\mathrm{CO}_{2}$ is from NPE-10 degradation according to the precipitation of white sediment as the results of reaction $\mathrm{Ba}(\mathrm{OH})_{2}$ with $\mathrm{CO}_{2}$. This result was also emphasized by the calculation of $\mathrm{CO}_{2}$ formed by back titration. It shows that NPE-10 resulted in $46.79 \%$ $\mathrm{CO}_{2}$ formation. The results from back titration obviously showed the incomplete degradation of NPE-10 by MEO. It should be noted that the results from degradation of organic pollutants are not always in the form of $\mathrm{CO}_{2}$ as their final product. An organic pollutant may also produce more simple compounds as its degradation product (Brillas 2014; Setiyanto et al. 2016). In respect to the result of $\mathrm{CO}_{2}$ analysis concentration, we therefore suggest that the remaining content were other organic compounds with smaller molecules.

\section{CHARACTERIZATION OF DEGRADATION PRODUCTS USING LC - MS}

Results from Table 1 obviously showed the potential of MEO for electro-degradation of NPE-10 and in producing smaller molecules. For this reason, we further analyse the degradation products of NPE-10 by LC-MS analysis. The LC-MS spectrum of NPE-10 before and after degradation is presented in Figure 6. As it can be seen, before degradation process, the NPE-10 shows peaks at retention time of
$5.00 ; 5.41 ; 5.75 ; 9.72 ; 11.07$; and $15.05 \mathrm{~min}$. This is due to the type of NPE-10 used in this study. The type is a technical grade, thus showing its impurities. However, the impurities of NPE-10 used in this study did not interfere. The degradation products were detected in Figure 6, as suggested by the two new peaks present in the LC-MS chromatogram of NPE-10 after degradation process (Figure 6) at retention time of 6.970 and $13.618 \mathrm{~min}$. The ion chromatograms and characterization of those compounds can be seen in Figures 7 and 8. As shown in Figure 7, for compound at retention time of $6.970 \mathrm{~min}$, the most significant ion is produced at $\mathrm{m} / \mathrm{z}$ of 413.29 , corresponding to the combination of benzylic cleavages $[\mathrm{M}-71]^{+}$and the shortened of polyethoxy chain $[\mathrm{M}-176]^{+}$. Whereas in Figure 8, for compound at retention time of $13.618 \mathrm{~min}$, the most significant ion is produced at $\mathrm{m} / \mathrm{z}$ of 603.92, corresponding to benzylic cleavage of $[\mathrm{M}-57]^{+}$. The benzylic cleavages and the shortened of polyethoxy chains are common for degradation of NPE compounds (Karci 2014; Li et al. 2018; Namara et al. 2012). According to the ion at $\mathrm{m} / \mathrm{z}$ of 603.92 , it seems that the terminal atom carbon of hydrophobic part of NPE-10 was firstly oxidized. And subsequently, the polyethoxylate chain which was continuously oxidized. Hence, resulting smaller molecules. Although the ion chromatograms in Figures 7 and 8 are not very informative in terms of structure elucidation, however, they provide an indication of the products of NPE-10 degradation and created a landscape for the future development of NPE-10 degradation process. 


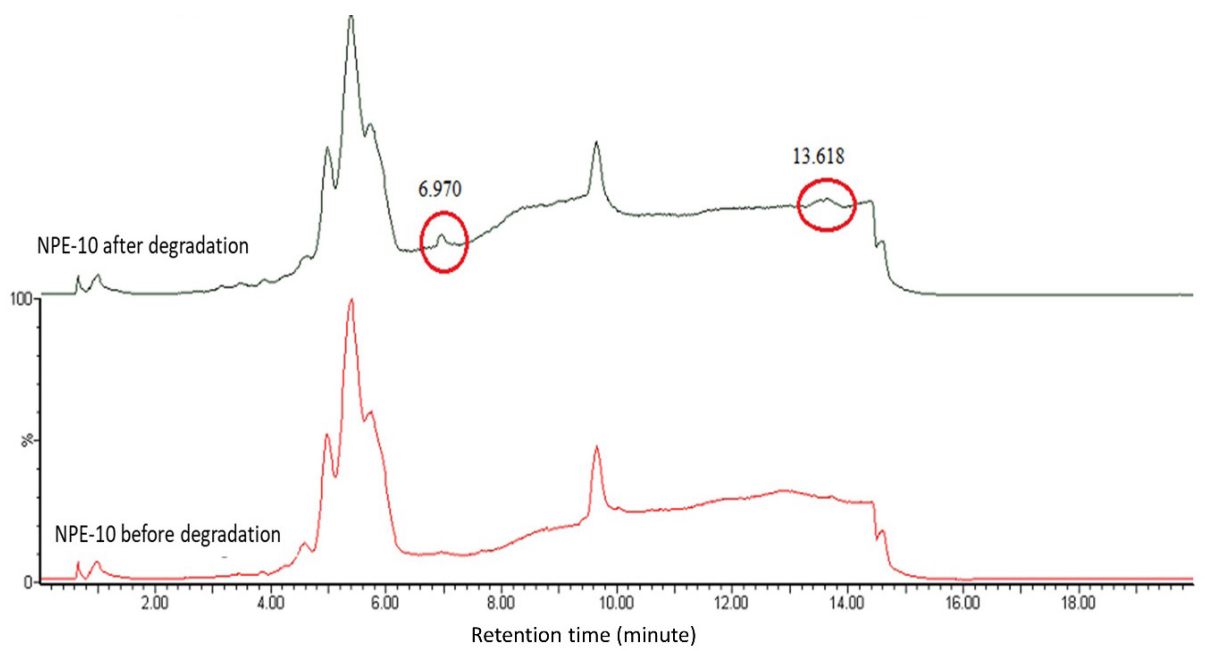

FIGURE 6. LC-MS chromatogram of NPE-10 before and after degradation by MEO

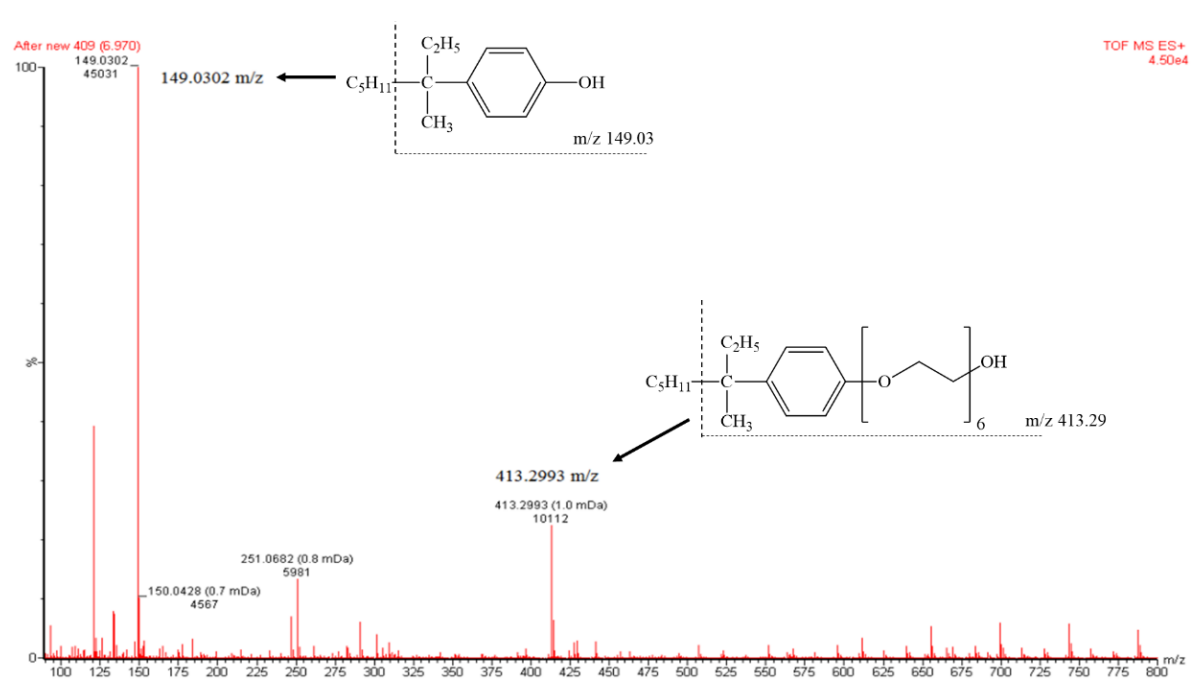

FIGURE 7. Ion chromatogram of degradation compound from NPE-10 at retention time of $6.97 \mathrm{~min}$

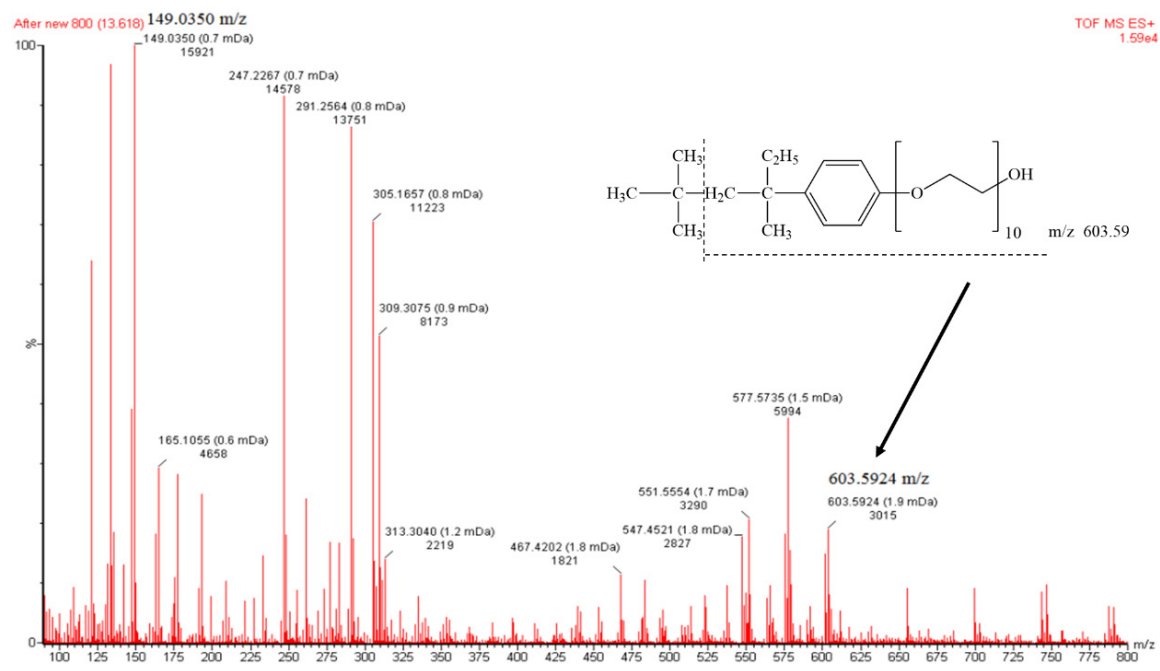

FIGURE 8. Ion chromatogram of degradation compound from NPE-10 at retention time of $13.61 \mathrm{~min}$ 


\section{DETERMINATION OF ORGANIC MATTER CONTENT USING PERMANGANATE VALUE}

The permanganate value denotes the number of milligrams of $\mathrm{KMnO}_{4}$ required in the oxidation of organic substances as suggested by the following reaction in (9) (Suslova et al. 2014):

$$
\mathrm{C}+\mathrm{MnO}_{4}^{-}+4 \mathrm{H}^{+}+\mathrm{e} \rightarrow \mathrm{CO}_{2}+\mathrm{Mn}^{2+}+2 \mathrm{H}_{2} \mathrm{O}
$$

Our results showed that before and after degradation of NPE-10 the $\mathrm{KMnO}_{4}$ value were 445.56 and 256.18 $\mathrm{mg} / \mathrm{L}$, respectively. The percent degradation of the organic compound was determined as $42.50 \%$. By summarizing the percentage value of $\mathrm{CO}_{2}$ and degradation organic compound, about $88 \%$ of NPE-10 was assumed to be degraded. This result is almost similar with the calculation of NPE-10 degradation by voltammetry technique as suggested by the degradation of $95.1 \%$ NPE- 10 . It is not surprising that the result of NPE-10 degradation by MEO using voltammetry technique is higher than the value resulted from back and redox titration. Because in voltammetry technique, the value recorded was based on the reaction on the electrode surface. Meanwhile in the back and redox titration, the values were obtained by using bulk solution. In addition, the more complex reaction may be occurred in a bulk solution results in lower value. In reverse, on the surface of electrode, the simpler and certain reaction occur as proposed in Figure 5, results in higher value. The results from voltammetry technique and titration mutually supports each other.

\section{CONCLUSION}

In conclusion, NPE-10 can be degraded by using MEO technology. About $88-95 \%$ of 1500 ppm of NPE-10 can be degraded by MEO within $35 \mathrm{~min}$. The presence of $\mathrm{Ag}(\mathrm{I})$ ionic catalyst improves the performance of $\mathrm{MEO}$ technology for degradation of NPE-10. Thus, we suggest that the MEO technology is a promising method for degradation of organic pollutant in waste water.

\section{ACKNOWLEDGEMENTS}

This research has been partially supported by Analytical Chemistry Research Group, Institut Teknologi Bandung (Indonesia) and the Ministry of Research and Higher Education of Indonesia through Riset PUPT 2017-2018. Authors would like to express gratitude to M.A. Majid Al Kindi for proofreading this manuscript and e-Layanan Sains, Indonesian Institute of Sciences for sample analysis.

\section{REFERENCES}

Balaji, S., Sang, J.C., Manickam, M., Kokovkin, V.V. \& Moon, I.S. 2008. Destruction of organic pollutants by cerium(IV)
MEO process: A study on the influence of process conditions for EDTA mineralization. Journal of Hazardous Materials 150: 596-603.

Brillas, E. 2014. A review on the degradation of organic pollutants in waters by UV photoelectro-Fenton and solar photoelectro-Fenton. Journal of Brazillian Chemical Society 25: 393-417.

Brigden, K., Santillo, D. \& Johnston, P. 2012. Nonylphenol Ethoxylates (Npes) in Textile Products, and Their Release Through Laundering. Greenpeace Research Laboratories Technical Report. University of Exeter.

Brooke, L. \& Thursby, G. 2005. Ambient Aquatic Life Water Quality Criteria for Nonylphenol. Report for the United States EPA, Office of Water, Office of Science and Technology, Washington, DC, USA.

Chung, Y.H. \& Park, S.M. 2000. Destruction of anilin by mediated electrochemical oxidation with $\mathrm{Ce}$ (IV) and $\mathrm{Co}$ (III) as mediators. Journal of Applied Electrochemistry 30: 685691.

Cox, M.F. \& Matson, T.P. 1984. Optimization of nonionic surfactants for hard-surfaces cleaning. Journal of the American Oil Chemist Society 61: 1273-1278.

David, A., Fenet, H. \& Gomez, E. 2009. Alkylphenols in marine environments: Distribution monitoring strategies and detection considerations. Marine Pollution Bulletin 58: 953-960.

Fawzy, A. \& Al-Jahdali B.A. 2016. Silver(I) catalysis for oxidation of L-glutamine by cerium(IV) in perchlorate solutions: Kinetics and mechanistic approach. Journal of Austin Chemical Engineering 3(4): 1037.

Forte, M., Lorenzo, M.D., Zarrizzo, A., Valiante, S., Vecchione, C., Laforgia, V. \& Falco, M.D. 2016. Nonylphenol effects on human prostate non tumorigenic cells. Toxicology 357 : 21-32.

Fuente, L.D.L., Acosta, T., Babay, P., Curutchet, G., Candal, R. \& Litter, M.I. 2010. Degradation of nonylphenol ethoxylate-9 (NPE-9) by photochemical advanced oxidation technologies. Industrial and Engineering Chemistry Research 49(15): 6909-6915.

Hernandez-Raquet, G., Soef, A., Delgenès, N. \& Balaguer, P. 2007. Removal of the endocrine disrupter nonylphenol and its estrogenic activity in sludge treatment processes. Water Research 41: 2643-2651.

Hussain, G. \& Silvester, D.S. 2018. Comparison for voltammetric techniques for amina sensing in ionic liquids. Electroanalysis 30: 75-83.

Juttner, K., Galla, U. \& Schmieder, H. 2000. Electrochemical approaches to environmental problems in the process industry. Electrochimica Acta 45: 2575-2594.

Karci, A. 2014. Degradation of chlorophenols and alkylphenol ethoxylates, two representative textile chemicals, in water by advanced oxidation process: The state of the art on transformation product and toxicity. Journal of Chemosphere 99: 1-18.

Li, C., Jin, F. \& Snyder, S.A. 2018. Recent advancements and future trends in analysis of nonylphenol ethoxylates and their degradation product nonylphenol in food and environment. Trends in Analytical Chemistry 107: 78-90. 
Liu, C., Lai, Y., Ouyang, J., Yang, T., Guo, Y., Yang, J. \& Huang, S. 2017. Influence of nonylphenol and octylphenol exposure on 5-HT, 5-HT transporter, and 5- $\mathrm{HT}_{2 \mathrm{~A}}$ receptor. Environmental Science and Pollution Research 24(9): 82798286.

Lu, J., Jin, Q., He, Y. \& Wu, J. 2007. Biodegradation of nonylphenol polyethoxylates under Fe(III)-reducing conditions. Chemosphere 69: 1047-1054.

Maki, H., Masuda, N., Fujiwara, Y., Ike, M. \& Fujita, M. 1994. Degradation of alkylphenol ethoxylates by Pseudomonas sp. Strain TR01. Applied and Environmental Microbiology 60: 2265-2271.

Mao, Z., Zheng, X.F., Zhang, Y.Q., Tao, X.X., Li, Y. \& Wang, W. 2012. Occurrence and biodegradation of nonylphenol in the environment. International Journal of Molecular Sciences 13(1): 491-505.

Martinez-Huitle, C.A. \& Ferro, S. 2006. Electrochemical oxidation of organic pollutants for the wastewater treatment: Direct and indirect processes. Chemical Society Reviews 35: 1324-1340.

Martins, A.F., Wilde, M.L., Vasconcelos, T.G. \& Henriques, D.M. 2006. Nonylphenol polyethoxylate degradation by means of electrocoagulation and electrochemical Fenton. Separation and Purification Technology 50: 249-255.

Matheswaran, M., Subramanian, B., Saan, J.C. \& Il, S.M. 2007. Silver ion catalyzed cerium(IV) mediated electrochemical oxidation of phenol in nitric acid medium. Journal of Electrochimica Acta 53: 1897-1901.

Muslim, M.S., Setiyanto, H. \& Zulfikar, M.A. 2018. Electrodegradation of nonylphenol ethoxylate (NPE-10) with silver ion catalyzed cerium (IV) in sulfuric acid medium. Proceedings of the 8th Annual Basic Science International Conference 2018. p. 90.

Namara, P.J.M., Wilson, C.A., Wogen, M.T., Murthy, S.N., Novak, J.T. \& Novak, P.J. 2012. The effect of thermal hydrolysis pretreatment on the anaerobic degradation of nonylphenol and short-chain nonylphenol ethoxylates in digested biosolids. Water Research 46: 2937-2946.

Olkowska, E., Ruman, M. \& Polkowska, Z. 2014. Occurrence in surface active agents in the environment. Journal of Analytical Methods in Chemistry 708: 1-15.

Paulenova, A., Creager, S.E., Navratil, J.D. \& Wei, Y. 2002. Redox potentials and kinetics of the $\mathrm{Ce}^{3+} / \mathrm{Ce}^{4+}$ redox reaction and solubility of cerium sulfates in sulfuric acid. Journal of Power Sources 109: 431-438.

Raju, T. \& Basha, C.A. 2005. Electrochemical cell design and development for mediated electrochemical oxidation $\mathrm{Ce}(\mathrm{III}) / \mathrm{Ce}(\mathrm{IV})$ system. Chemical Engineering Journal 114: $55-65$.

Ren, X. \& Wei, Q. 2011. A simple modeling study of the Ce(IV) regeneration in sulfuric acids solutions. Journal of Hazardous Materials 192: 779-785.

Setiyanto, H., Agustina, D., Zulfikar, M.A. \& Saraswaty, V. 2016. Study on the Fenton reaction for degradation of remazol red $\mathrm{B}$ in textile waste industry. Molekul 11(2): 168- 179.
Setiyanto, H., Saraswaty, V., Hertadi, R., Noviandri, I. \& Buchari, B. 2015. Determination of the reactivity of the anti - cancer nitrogen mustard - mechlorethamine: A cyclic voltammetric investigation. Analytical and Bioanalytical Electrochemistry 6: 657-665.

Setiyanto, H., Saraswaty, V., Hertadi, R., Noviandri, I. \& Buchari, B. 2011a. Chemical reactivity of chlorambucil in organic solvents: Influence of 4-chloro butyronitrile nucleophile to voltammogram profile. International Journal of Electrochemical Science 6: 2090-2100.

Setiyanto, H., Saraswaty, V., Hertadi, R., Noviandri, I. \& Buchari, B. 2011b. Cyclic voltammetric study of chlorambucil in the presence of 4-chloro butyronitrile in aqueous solution. International Journal of Chemical Technology Research 3(4): 1986-1992.

Shufaro, Y., Saada, A., Simeonov, M., Tsuberi, B.Z., Alban, C., Levin, A.K., Shochat, T., Fisch, B. \& Abir, R. 2018. The influence of in vivo exposure to nonylphenol ethoxylate 10 (NP-10) on the ovarian reserve in a mouse model. Reproductive Toxicology 81: 246-252.

Sumathi, T., Sundaram, P.S. \& Chandramohan, G. 2010. A kinetic and mechanistic study on the silver (I) catalyzed oxidation of L-alanine by cerium (IV) in sulfuric acid medium. Arabian Journal of Chemistry 4: 427-435.

Suslova, O., Govorukha, V., Brovarskaya, O., Matveeva, N., Tashyreva, H. \& Tashyerev, O. 2014. Method for determining organic compound concentration in biological systems by permanganate redox titration. International Journal Bioautomotion 18(1): 45-52.

Wang, J. 2000. Analytical Electrochemistry. 2nd ed. New York: John Wiley \& Sons.

Henry Setiyanto*, Muhammad. Muslim Syaifullah, I Made Adyatmika, Dian Ayu Setyorini, Muhammad Yudhistira Azis \& Muhammad Ali Zulfikar

Analytical Chemistry Research Group

Institut Teknologi Bandung, Bandung

Indonesia

Henry Setiyanto*

Center for Defense and Security Research

Institut Teknologi Bandung

Bandung 40132

Indonesia

Vienna Saraswaty

Research Unit for Clean Technology

Indonesian Institute of Sciences, Bandung

Indonesia

*Corresponding author; email: henry@chem.itb.ac.id

Received: 2 January 2020

Accepted: 12 July 2020 